\section{ANTIPODEANISM, AND CHARLES DICKENS' IMPERIALIST UNDERTAKINGS IN DEPICTING AUSTRALIA}

Keyvan Allahyari ${ }^{1}$

\begin{abstract}
Charles Dickens (1812-1870) was, at once, the most prominent English novelist of the mid-nineteenth century and one of the most industrious workers in facilitating the emigration of the British lower classes to colonial Australia. Throughout his novelistic and journalistic depictions of Australia, Dickens draws upon the textual tradition of the imaginary construction of the southern continent. His writings, therefore, function as complementing pieces for the discursive puzzle of 'Australia' and 'the Australian' from the Empire's point of view. I will argue that Dickens' picture of Australia echoes the tenets of the centuries-held discourse of Antipodeanism. Under the guise of an impartial outlook, Dickens' writings about the southern colony act as a hegemonic drive to ease the dissemination of imperialist ideas, hence the material domination of Australia. The powerdirected aspect of these items, however, remains hidden under a philanthropic veneer. In addition, economic and spatial availability of Australia could not be justified in Dickens' words, unless the core binarist system of representing the colony in relation to the metropolis is maintained.
\end{abstract}

\footnotetext{
${ }^{1}$ PhD Candidate, Department of English University of Auckland
}

\section{The Discourse of Antipodeanism, and colonial justification}

Originally, the Antipodes was a part of the cartographic notion of terra incognita or the unknown land. From classical times, representations of the southern continent extended their influence into different disciplines, ranging from quasi-scientific experimentations to satirical sketches. These documents were shaped around a geographical understanding that beyond the ends of the earth, there must exist places, spaces and peoples unknown to the producers of those texts. The notion of the Antipodes appealed to two groups of writers, firstly, to mathematically-based astronomers who regarded the concept of a spherical earth as fundamental to their discipline and, secondly, to philosophers and writers of fiction for whom the idea of the existence of antipodal regions beyond the reach of empirical knowledge provided a space for intellectual and creative freedom. Even in these fields, however, authors emphasized the lack of information about the very existence of antipodal inhabitants. In this way, the notion of the Antipodes was borrowed from cartography and appropriated into fictional and philosophical writing. This concept was used, in turn, as an inaccessible (non)place for philosophers and theologians to simulate their preferred ideological systems.

The development of world maps during the Renaissance lent a scientific credibility to the European imagination of the Antipodes. The Pacific, then, became a finite and potentially accessible part of European knowledge. In "Inscribing the Emptiness," Simon Ryan considers how cartographic representations of Australia with their misleading claims to 'accuracy' led to the imaginary creation of the country "as a 
tabula rasa to produce the continent as an inverted, empty place desperately requiring rectification and occupation" (Ryan 1994: 116). The reason for this, in part, is that in the course of the sixteenth century, the process of exploration and colonization of the New World required the constant updating of knowledge about those spaces in the form of scientific descriptions of the world. Sketching of the southern continent, however, was still coupled with the European imagination and maps of the Antipodes bore what Alfred Hiatt calls the "metacartographic function of antipodal land." In Terra Incognita, Mapping the Antipodes before 1600, he writes,

By the last decade of the sixteenth century, and the first decade of the seventeenth, cartographers and writers had begun to use the southern land as the locus of allegory and satire, directed, in return to Menippean traditions, at the follies of the known world. The elusive status of nondum cognita had not been resolved by discovery and exploration, so the blank space of terra incognita invited an efflorescence of representation: a flourishing of images, but also the flourishing of the idea of the unknown southern land, with all its possibilities, as the mirror of the Old World, the mimic of the New. (Hiatt 2008: 225)

Mirroring the Old World by picturing the Antipodes at the periphery of European cartographic knowledge and the creative imagination created the textual tradition of representing the Antipodes with a traceable metaphorical core. Richard Brome's The Antipodes (1640) is one example of the long list of works that incorporated the metaphorical structures of the southern continent. The plot of this five-act play is set around the psychological issues of the Joyless family. The protagonist, Peregrine, is obsessed with the literature of travel, especially with Mandeville's Travails and their images of antipodean monsters. Peregrine's father, Master Joyless is a former widower who has married a seventeen-year old girl, Diana, of whom he is overtly jealous. A physician called Hughball and a nobleman named Letoy combine their efforts to treat the Joyless family's obsessive problems via the therapeutic function of theatre. To do this, Hughball makes Peregrine drink a powerful sleeping potion and later they all move to Letoy's estate. Upon waking, Peregrine is fooled by the actors into thinking that he has actually travelled to the Antipodes where a series of inverted morality codes unfolds in a made-up society called "antiLondon", a distorted mirror-image of the English society of the dramatist's day. There, the victims of disasters such as fire suffer severe consequences like banishment, imprisonment and death, young women woo bachelors, servants rule their masters, and gentlemen behave in the crudest manner. To make things more chaotic, Peregrine crowns himself king of the Antipodes. These tensions, however, do not override the generic expectations of the play. Peregrine consummates his marriage when encountering his wife as the Queen of the Antipodes and Joyless is happily reunited with Diana after she resists Letoy's advances. In addition, it turns out that Letoy is Diana's real father and he had only intended to test her virtue. Relying on the common cartographic understanding of his audience, Brome brings a geographical metaphor into play. The world is composed of two hemispheres symbolizing two opposite sides of human nature in terms of rationality. The metatheatrical journey of the Joyless family to their unconscious territory in the Antipodes develops into an 
allegory of encountering the distorted truth of the self. Having said that, crossing the equator suggests trangressing over the line of sanity/insanity, conscious/unconscious: "This "line", signifying psychic and moral equilibrium is, of course, the equator" (Fausett 1993: 71).

Interest in austral themes formed a flexible body of knowledge rather than a fixed imaginary picture to attribute to inaccessible exotic peripheries. The 'Antipodes' is essentially a malleable concept which was effectively appropriated by different discourses (artistic/imperial/political) to authorize, solidify and, at times, degrade the ideological inclinations of the center. As the studies of Hiatt and Ryan suggest, the Antipodes has functioned to dramatize Eurocentric concerns, delimiting the ideological outskirts by pushing the antipodean to the farthest extremes. Symptomatic of the characteristic flexibility of the discursive formation of the Antipodes is the way it loaded British imperial discourse with a hegemonic force. This understanding of the Southern Continent ties effectively in with the logic of expelling vagabonds from the center to the periphery of the world, then justifying the legal aspect of the transportation of the convicts. In Shaw's words, "[t]his was probably the result of combining two vague ideas of primitive justice - that a society should get rid of its troublesome members (just as it had banished them in the past), who, at the same time, might be asked to carry out arduous, dangerous or unpleasant tasks for the common good" (Shaw 1996: 23). There lay a tangible connection between colonization, the Antipodes and social concerns about surplus population. Knowing this, it is no surprise that the English Parliament was active from the mid- $16^{\text {th }}$ century in passing laws to expel unfavorable residents to beyond the seas. Shaw records

In England, a Vagrancy Act in 1547 had authorized magistrates to hand over idle persons who refused to work to masters who would compel them to, thus making them virtually slaves; though this Act was repealed in 1550, Parliament revived the principle in 1598 when it enacted that any rogues appearing 'dangerous to the inferior sort of people' or 'such as will not be reformed of their roguish kind of life' were to be 'banished out of this realm ... and conveyed unto such parts beyond the seas as shall be at any time hereafter assyned for that purpose by the Privy Council ... or otherwise be judged perpetually to the galleys of the realm. (Shaw 1996: 23)

By the late $18^{\text {th }}$ century, the still unproved prophecies about Australia were backed officially by Captain Cook's first reported observations of the land. A prolific diarist, Cook wrote an account which, 17 years later, helped to convince Parliament that the British could occupy the newly found continent, for the simple reason that the Indigenous Australians had no legal claim to the land, nor had any sense of ownership or property. Accordingly, Cook's documentation of the already ordained pattern of the antipodean and the ensuing occupation of the land can be considered to be the first instance of operating the metaphoric system of representing Australia as a colony. Alice Brittan comments on the aftermath of Cook's contention: 
The judgment that Australia was terra nullius [meaning in Latin 'a land belonging to no one'] meant not only that the British could claim legal sovereignty over the entire continent, effectively declaring the Crown as the new and undisputed owner, but also that they did not need to negotiate any formal treaties with the Aborigines. Why would one make a deal with people who never held title to the land in the first place? (Brittan 2007: 73)

Imperialist discourse, then, in its heyday, borrowed the metaphorical construction of the Antipodes in order to clear the path for the material domination of the land. In Possessing the Pacific, Stuart Banner elaborates on the implications of the concept of terra nullius in Australia. In his view, among British colonies, Australia, being a penal colony, was a comparatively easier target for land seizure since the government rather the missionaries or tradesmen started the occupation of the land. This phenomenon left so little to fret about that the early discussion over terra nullius had almost nothing to do with the acquisition of land, as though under "English property law, the Aborigines did not exist" (Banner 2007: 37).

The impulse to purge society from the malignance of rogues maintained its force well after the abolition of the transportation of convicts to New South Wales in 1840. The Colonial Office came up with a new designation of 'exiles' to forward those prisoners to "the Australian mainland with pardons after they had served a term in British penitentiaries." This decision resulted in disembarking a total of " 1,727 exiles at Port Phillip between November 1844 and February 1849" (Sturma 1983: 51).
Having established what Edward Said calls "structures of attitude and reference" (Said 1993: 62), the previously wrought textual fictionality of Australia smoothed any conceptual hindrance out in a way that, after its discovery, the occupation of Australia appears to have been the most expected treatment of all. This understanding of Australia, I will later suggest, affected its perceived image as represented in Charles Dickens' writings. Dickens' profession, journalistic and fictional, can be viewed with an awareness of the reciprocal affectivity of imperial attitudes circulating in the texts of his time about Australia and his own related writings. The central argument of this study revolves around the idea that Dickens, in his journalistic and literary treatment of Australia, could not and did not go far beyond the textual picture that had been already depicted for the southern continent.

\section{Dickens and the Poetics of the Textuality of Australia}

Typical of a Victorian writer, Dickens always intended to be socially serious, both as a journalist and a novelist. As Monroe Engel puts it, "[t]here can be no essential separation between Dickens the novelist and Dickens the citizen and man of opinions who lived in England from 1812 to 1870 " (Engel 1956: 947). Social concern merged with the popularity of his writings and his well-known reputation as the champion of the poor elevated his position from an admired writer to an educator and pronouncer on the public values of Victorian middle class. In Mukherji's words,

The role of editor combined with the role of educator was one which was extremely important to 
Dickens. It makes for an extensive, intimate and developing relationship between the journal and his public, and between the serialised novel and his public. Hence the journals, like the novels, had to reflect and acknowledge the values and experience of their readers-by and large the English middle class. (Mukherji 1981:9)

Dickens was also very well received in Australia in his time. In 1873, this aspect of Dickens's work was discussed at length in the Sydney Morning Herald under the title of Charles Dickens as an 'Observer and Reporter of Facts.' Dickens's earnest tone, showed itself nowhere better than in his passion for writing about Australia. In the first of the more than one thousand issues of Household Words, Dickens openly expresses his expectant outlook on the southern continent:

It is unquestionably melancholy that thousands upon thousands of people, ready and willing to labor, should be wearing away life hopelessly in this island, while within a few months' sail - within a few weeks when steam communication with Australia shall be established there are vast tracts of country where the man who is willing to work hard (but that he must be, or he had best not to go there), can ever know want. (Lansbury 1988: 58-59)

Dickens, who like many of his contemporaries never visited the land, came to know Australia through texts. The most influential of these texts was the Australian Handbook (1849) by Samuel
Sidney, who had written many articles on the topic of Australia in HouseholdWords. The Handbook which strengthened the idea publicized in Household Words that the sunny lands of the Antipodes could work as a future Arcady for the British working class. The significance of the impact of Australia's textual construction on Dickens' conception of the place reveals itself in the fact that his idea of the land evolved through gradual encounters with different texts about the continent. Within almost a decade there occurred an effective shift of attitude towards Australia in the author of Pickwick Papers (1837) and David Copperfield (1849-1850). Lansbury, investigating Sidney's Handbook's influence on Dickens, discusses how Dickens' Australia matured from the idea of Botany Bay-the distant goal for dismissed British convicts founded after America's refusal to receive any more convicts-in Pickwick Papers which "reveals no awareness of Australia other than a place of exile and despair," into an Australia which bears the promise of the British working men's Arcady and also an egalitarian society which gives "David Copperfield a new dimension and a credibly happy ending" (Lansbury 1971: 12-13). This adjustment of orientation towards Australia is not restricted to the novels. In his social role as an educator, Dickens cooperated closely with Caroline Chisholm, the social worker and Sidney's protégée, and in Household Words publicized her work for the Family Colonisation Loan Society, which was encouraging the unfortunate population of England, both financial and social, to migrate to Australia.

There is no evidence that the question of the rightness of Australia's occupation ever troubled Dickens' mind. After 
becoming acquainted with Sidney and Chisholm in 1849, he actively imported the profit-making motif into his Australiarelated writings. Household Words regularly published articles that can be called 'tales of success in Australia.' What makes the depiction of Australia in Household Words economically significant is the fact that the time period in which it was published (1850-1859) was the decade in which gold was discovered in New South Wales and Victoria. As the editor in chief Dickens was informed about Australia's living conditions by writers such as William Howitt and Richard Horne, who regularly contributed to his journal. Like so many others, these writers were attracted by the possibility of discovering gold in Australia. Interestingly, before their journey, they were commissioned by Dickens to record their experiences in Australia for publication in Household Words. For an audience who knew very little about life in such a fresh geographical entity, these accounts aroused much interest. An inherent component of this narrative was the fact that Australia was being exposed to British society as being financially rewarding. As Margaret Mendalwitz writes in this regard:

All [of these articles] are part of the body of literature that emerged with gold rushes, literature that helped to shape a new way of thinking about life in colonial Australia. Australian life was now being depicted as thrilling and different with an exciting future ahead, a country standing apart from its stark convict beginnings. Life in the new world was being presented as offering opportunities for a new start, radically different from that in early industrial
Britain. Australia had just won the golden lottery, and the world was fascinated. (Mendalwitz 2011: xviii)

Economic and special availability of the land could not be justified in Dickens' words, unless, disguised as philanthropic intentions, the binarist system of representing the colony in relation to the metropolis, which has already been textually articulated, was maintained. Still, Dickens was not artlessly innocent. In textualizing Australia, he 'distances' the 'Australians', at home and abroad, on the two interconnected levels of class and of race.

\section{Dickens, the Mythopoet: Towards an Australian Identity}

Two of Dickens' novels, David Copperfield, and Great Expectations, both written during the period that Dickens was contributing to the Family Colonisation Loan Society and Urania Cottage, include a list of characters who, willingly or otherwise, travel to the southern colony. This list includes Wilkins Micawber, an eccentric constantly in debt, Little Em'ly, seduced and disrespected by a wastrel, Daniel Peggotty, a poor fisherman whose loved niece is ruined, Martha Endell, a prostitute, Charles Mell, a humiliated man because his mother lives in an almshouse and, most famously, Abel Magwitch, a convicted criminal. All these characters fall into three general categories of the socially or financially unfit, the fallen woman and the transported convict.

The shared feature among all these characters (that none of them is welcomed in the centre) blurs the borderline between voluntary emigration and enforced transportation. In other words, they all move to Australia because living in England, for different reasons, has become 
almost unworkable. For these characters, setting off to Australia is itself a testimony of having failed in the metropolis. Significantly, a remarkable transformation, in one way or another, is awaiting all of these British ex-centrics. Mr. Micawber rises to become the district magistrate for Port Middlebay. Little Em'ly achieves the Victorian female ideal to live as a lady. Mr. Pegotty, reunited with his niece, starts a peaceful life, Martha Endell marries a decent farm laborer, and Charles Mell becomes Dr. Mell of the colonial SalemHouse Grammar School, Port Middlebay. Even the initially animalized Magwitch, though still detested in the centre, starts to do well on the periphery. Hence, Australia's utopian refuge manages to provide its settlers with their missing metropolitan-based feature. Once in Australia, they start to prosper by benefiting from qualities far different from (not to say opposed to) those needed in the mother country.

In this seemingly innocent philanthropic promise of reward for the "not-good enough', in Lansbury's words, "[i]mplicit was the belief that the convict like little Em'ly or Magwitch, would be purged of guilt in Australia" (Lansbury 1988: 61). In this way, Dickens in assuming the very idea of retribution, paraphrases the centuries-old concept of the perversity associated with the Antipodes and, accordingly, charges the binarist system with the superiority of England over the colony. There comes a veiled syllogism. If retribution occurs, there must have been a deviation from the 'normal.' Inevitably entangled within the discourse of Antipodeanism, Dickens' discursive picturing of Australia cannot help but rearticulate the statement of the deferral of the colony to the centre. Here, again, it is the mother country that benefits the most from the social erasure of its corrupt subjects. In this respect Elleke Boehmer writes ' $[\mathrm{a}] \mathrm{s}$ in Dickens, Australia in the novel acts to relieve social and sexual embarrassment. While fallen women redeem themselves and Micawber can become magistrate, gender and class proprieties are preserved in Britain" (Boehmer 1995: 28).

At this point a technical question seems to be valid. How is it that all of these characters, unfortunate in their motherland and obviously missing some necessary qualifications to succeed, prosper in Australia? Any explanation other than the underlying assumption that the qualities needed to progress in the Antipodes are far from similar and are, in some ways, even opposite to those required in England might unsettle Dickens' sense of fictional plausibility. Dickens' writings about Australia pass on the association of the assumed primitiveness of the "noble savage' with the qualities necessary for the 'distanced British' to make a fortune in the Antipodes. In a parallel fashion, this idea is given voice to in Household Words by Samuel Sidney. In his articles on emigration, he stabilized the notion that "[g]ood spirits were more to be desired in the Australian bush than good sense, whereas literary texts and intellectual interests would guarantee failure" (Lansbury 1971: 14). Thus, Dickens implies a comparability and compatibility of the general perversity associated with the perceived notion of Australia with a digression from metropolitan norms in the lower-class British immigrants. He fuses the indispensable perversity/inferiority of the 'racial other' with the deficiencies of the 'social other'. This 'estrangement' of the familiar moves in a counter direction to the process of familiarization of the 'strange', as seen in early imaginary 
representations of the Antipodes, but equally operates to naturalize Australia's occupation.

Taking advantage of the adaptability of imperial discourse, Dickens imports the metaphorical structure of the upside-down status of the Antipodes into his writings about those emigrants or transported subjects who, by British norms, cannot be called 'ladies' or 'gentlemen' such as Agnes or David Copperfield. Nevertheless, Dickens is not the only writer to utilize the imaginative construction of the colonies. Elleke Boehmer argues that,

The transferability of empires' organizing metaphors is one of the key distinguishing characteristics of colonialist discourse- one that made possible the intertextuality of writing under empire. Itinerant and adaptive, focusing colonial myths, activating imperialist energies, what we shall call the traveling metaphor formed an essential constitutive element of an intensely imagined colonial system. (Boehmer 1995: 52)

Identification of the British 'Australian' with the native 'Australian' manages a pattern of alteration. However, this is not an ideological parameter per se and has more materially-oriented goals. Whatever Dickens published about Australia had the shaping teleological denominator of economic interest at its heart. Dickens does his best to shed light on the way that the immigrants might live in Australia. The clarifications include the climatic and geographical characteristics of the area, harsh and pleasant days that immigrants might encounter, the good to be trusted and the bad to be aware of, things, that when there, they are in need of, and even professional tips. In many ways, Dickens' words on Australia are capable of being likened to a long and continuous advertisement for emigration. It was Dickens himself who, for the first issue of Household Words wrote 'A Bundle of Emigrant's Letters.' The materials for this part were letters from working men in Australia provided by Caroline Chisholm. In the first of these letters, an emigrant, writing to his wife, hopefully expresses his delight about food prices in Australia:

I almost forgot to say that I wanted something for my supper saturday $[\mathrm{Sic}]$ night so I went to the butchers to get some chops and I had a pound and half of the loin $2 \mathrm{~d}$ fine sheep hearts and a sheep kidney and how much do you think they was only $4 \mathrm{~d}$ the lot a fine bullock's kidney is only 2 and a very fine shin of beef $4 \mathrm{~d}$ or $6 \mathrm{~d}$ what will the London butcher say to this. (qtd. in Mukherji 1981:12)

Mukherji comments on this letter that, "[i]f we contrast these prices with budget estimates for 1845 and 1851 we can see the man eating a quantity of meat at one meal which a working class family with three children could not afford for a week in England" ( Mukherji 1981:12).

Dickens translates the fictional into the journalistic and vice versa and in this way sets up an Australian Dream most appealing to lower classes. However, once out there, the myth of Australia-goers is not yet over. Charles Dickens rearticulates the alienation of the 'Australians', both racial and social, in regard to the threat that 'they' can pose to metropolitan 
economic objectives. In doing so, Dickens' fictional world entirely takes the Aborigines' very actuality for granted. Those characters who are in contact with Australia, in one way or another, never bother to ask anything about its native settlers. Apparently, the natives are, to Dickens, still not official owners of the continent and cannot possibly have an influence on the white settlers' financial or ethical transformation.

In addition, in Household Words, whenever it comes to writing about the "natives," Dickens presents them as animal-like creatures who are almost beyond any hope of being schooled. In a letter, by a female emigrant named ' $\mathrm{C} \mathrm{S}$ ', edited by Dickens himself, the Aborigines are talked about as follows:

They are the most hideous sort of folks you can imagine and much like very old monkeys and, when wild, go quite naked, which they like best. Government has had houses built for them, but they will not stay in them, and schools for their children, but they will not let them attend........ [sic] They are almost black, but have long silky hair, of which they are very proud. Altogether one cannot but pity them. There would be a wild field for $\mathrm{Mr}$ Malthus's philanthropy, here, in trying to civilise them the young ones, I mean. (Mukherji 1981:12)

There comes such a silencing, since, if the Aborigines could find any notable existence in the conceptual realm, their land could no longer be textually evacuated and subsequently the old trope of terra nullius would come under question. Therefore, ignoring the Australian Aborigines clears the path for immigrants to pursue their expansionist goals in Australia without the hindering compunction of seeing themselves as intruders. Preoccupied with preserving social and moral proprieties at home, Dickens utilizes Australia as a safety valve for the claustrophobic social conditions of England. However, he never opens up a space for the possibility of the appreciated return of the white 'Australians,' no matter how reformed, because back in the centre, they still represent a threat that would unsettle the English sexual or social gravities. Living in Australia, it seems that, the settlers have inherited something of the toppling capacity of the Antipodes.

The theme of "The Convict's Return," though perhaps too unnerving to be touched very often, remained a part of Dickens' preoccupation with Australia throughout his long novelistic career. As early as 1837, in The Pickwick Papers, the story of John Edmund is told to the Pickwickians by the clergyman of Dingley Dell. There, Edmund, after a miserable childhood is transported for 17 years for robbery. While in Australia, he is disowned by his father, and is thought to be dead. Back in his village in England, he is unrecognized by all but his father, who dies when he recognizes his son. After serving the vicar for three years, he dies "contrite, penitent, and humbled" (Dickens 1837: 62). The vicar brings his story to the end that "[n]o one save myself knew in that man's lifetime who he was, or whence he came-it was John Edmunds, the returned convict" (82). Great Expectations $(1861$,$) one of Dickens' most mature$ books, expresses the same metaphorical implications. Interestingly, Dickens' narration of the convict's return is 
motivated by his own engineered picture of the colony in the late 1840s and 1850s. That is to say, down under in Arcady, Magwitch can do well and become rich. However, as Alice Brittan writes "when former convicts prospered in Australia, their success was often seen as a confirmation that the moral order of the place was as upside-down as its position on the map" (76). Likewise, Magwitch's wealth, even decently earned, has had a tinge of the antipodean power to disturb the centric social hierarchies. Back in London, he is looked down upon distastefully like a repressed sordid memory reappearing in the conscious mind of the Empire. Wealthy or not, he is still a marginalized criminal who, to everyone's relief, was forced out of the nation. Moreover, his Britishness is now in doubt. When, for the first time, Pip divulges the secret of Estella's father to Mr. Jaggers, he introduces Magwitch as "Provis - from New South Wales" (375). A revived danger from the periphery to the centre, Magwitch must be gagged and his money must be rejected. At the time of the publication of the novel the problem of the criminalized poor slinking around, those who in Magwitch's words had no other choice but to spend their lives "[i]n jail and out of jail," until they got "shipped off" (319) to the colony, was still being seriously considered. All this happens when the convict transportation to New South Wales was abolished as early as 1840. However, the ideological charge behind the convict transportation system did not cease to work. In fact, the impulse to push to the outermost periphery acted upon the convicts well after their return. Back in the centre, they were not welcome even in the slums of London. An unsigned article entitled "Convicts, English and French," which was published in Household Words on 24 February 1855, discussing how convicts and ex-convicts should be dealt with reads,

The British public knows very little of what becomes of convicts...We can't have them continually sailing up and down the seas in quest of a colony which will take them in. We would rather not have them walking about Regent Street, with bludgeons, pitch-plasters, chloroform sponges, and slipknotted handkerchiefs in their pockets. They are an eyesore to us even in Woolwich or Portsmouth yards, skulking among the frank, jovial, open-faced men-of-war's men and the smart stalwart soldiers. We grumble against the pet prisons, the horticultural show-houses of rascality, the menageries of crime. (qtd. in Tamai 2002: 86)

In his seminal work on the history of convict transportation to Australia, The Fatal Shore (1988), Robert Hughes expands on the idea that convicts formed a new subculture of crime in early Victorian England. This sort of class consciousness managed to justify the transportation of convicts to the other side of the world. Dispatching the convicts to the Antipodes, however, was only the extreme materialization of the impulse to deactivate the harmful existence of this class. For this reason prisons were regarded by the public as the concentration centers of criminals. As he puts it:

They were the republics of a sublimated criminal class; they belonged to the antipodes of crime, not to the bright world of authority, which they represented 
only in a nominal way. In due course, this train of thought would provide the underlying logic of transportation to Australia. For transportation made sublimation literal: It conveyed evil to another world. (Hughes 1987: 94-5)

To sum up, in textualizing Australia, Charles Dickens's writings function as complementary pieces that mould the ultimate puzzle of 'Australia' and 'the Australian' from the Empire's point of view. However, the power-directed aspect of these items is hidden under a veneer of humanism and philanthropy. Dickens' inscription of Australia moves from being merely representative towards becoming highly performative. Recycling his preoccupations in literary and journalistic writings, he begets a Dickensian textual life for Australia which becomes particularly important for the reason that his construction of the place does not stop at being seen as simply aesthetic and reinforces the energies which effectively shaped white Australian society. If Dickens, the most remembered writer of the age, seeing and interpreting the place through the lense of the discourse of Antipodeanism, was a borrower of metaphoric representations of Australia, he, in his own turn, became an authoritative creator of the imaginative construction of the land. Having incorporated the tenets of the previously held tradition, Dickens' depiction of Australia could hardly do anything but act as a working hegemonic impetus to ease the process of disseminating imperialist ideas, hence the material domination of Australia. Dickens' representations of Australia constantly connect the textuality of Empire to its materiality.

\section{References}

Banner, Stuart. 2007. Possessing the Pacific: Land, Settlers, and Indigenous People from Australia to Alaska. Cambridge: Harvard University Press.

Boehmer, Elleke. 1995. Colonial and Postcolonial Literature. Oxford: Oxford University Press.

Brittan, Alice. 2007. Australasia. The Routledge Companion to Postcolonial Studies. Ed. John McLeod. London and NewYork: Routledge, 72-82.

Dickens, Charles. 1996. Great Expectations. Ed. Janice Carlisle. Boston: Bedford.

Dickens, Charles. 1837. The Pickwick Papers. London: Nottingham Court Press.

Engel, Monroe. 1956. The Politics of Dickens' Novels. Modern Language Association PMLA 71, 5: 945-974.

Fausett, David. 1993. Writing the New World: Imaginary Voyages and Utopias of the Great Southern Land. Syracuse, N.Y.: Syracuse University Press.

Hiatt, Alfred. 2008. Terra Incognita : Mapping the Antipodes before 1600 London: British Library.

Hughes, Robert. 1987. The Fatal Shore, A History of the Transportation of Convicts to Australia, 1787-1868. London: Collins Harvill.

Lansbury, Coral. 1988. Charles Dickens and His Australia. Interpreting Australia. Eds. Tony Delamothe and 
Carl Bridge. London: The Center for Australian Studies: 55-71.

---. Terra Australis Dickensia. 1971. Modern Language Studies 1, 2: 12-21. Mendelawitz, Margaret. 2011. Charles Dickens' Australia, Selected essays from Houshold Words 1850-1859. Sydney: Sydney University Press.

Mukherji, Sanji. 1981. Attitudes to Charity and the Empire in Charles Dickens. Economic and Political Weekly 16, 42/43: 9-18.

Ryan, Simon. 1994. Inscribing the Emptiness, Geography, Exploration and the Construction of Australia. De scribing Empire, Post-colonialism and Textuality. Eds. Chris Tiffin and Alan Lawson. London and New York: Routldge: 115-130.

Said, Edward. 1993. Culture and Imperialism. London: Vintage.

Shaw, A. G. L. 1966. Convicts and the Colonies :A Study of Penal Transportation from Great Britain and Ireland to Australia and Other Parts of the British Empire. London: Faber.

Sturma, Michael. 1983. Vice in a Vicious Society: Crime and Convicts in Mid Nineteenth Century New South Wales St. Lucia: University of Queensland Press.

Tamai, Fumie. 2002. Great Expectations Democracy and the Problem of Social Inclusion. The Japan Branch Bulletin of the Dickens Fellowship. No. 25: 55 67. 